\title{
World Congress of \\ Gastroenterology Meeting, Canada, September 9 to 14, 2005
}

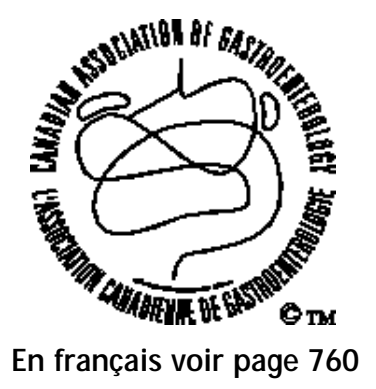

\author{
Richard N Fedorak MD FRCPC \\ President, World Congress of Gastroenterology 2005 Canadian \\ O rganizing Committee
}

\author{
Philip M Sherman MD FRCPC \\ Vice President, World Congress of Gastroenterology 2005 Canadian \\ O rganizing Committee; President, Canadian Association of \\ Gastroenterology
}

B y now you have heard that the $C$ anadian Bid Federation has succeeded in winning the bid to hold the next W orld C ongress of $\mathrm{G}$ astroenterology meeting in M ontreal in September 2005. The Canadian Bid Federation, which worked on behalf of the Canadian A ssociation of $G$ astroenterology ( $C A G$ ) and its members, is indeed proud to have brought this meeting to $C$ anada and is assured that it will provide an enormous dividend for Canadian G astroenterology.

$\mathrm{H}$ aving secured the $\mathrm{W}$ orld $\mathrm{C}$ ongress of $\mathrm{G}$ astroenterology 2005 meeting, the real work now begins! To initiate the process, the CA G has constituted the World Congress of Gastroenterology 2005 Canadian Organizing Committee (Table 1). This committee will work with the CA G and the Organisation Mondiale de Gastro-Entérologie (OMGE) and the Organisation Mondiale D'Endoscopie Digestive (OMED) (the two parent bodies that co-host the World Congress of $\mathrm{G}$ astroenterology Meeting) to develop and stage an enormously successful meeting.

The CA G is fortunate in that four of its senior members also serve on committees of the OMGE and OMED. Doctors Robert Bailey, Grant Gall, Norman Marcon and A lan Thomson hold executive positions in these two parent organizations and will be able to assist the W orld C ongress of $\mathrm{G}$ astroenterology $2005 \mathrm{C}$ anadian O rganizing Committee in its liaison with the OMGE and OMED.

The OMGE and OMED have selected two meeting planners to support the development and implementation of the W orld C ongress of G astroenterology 2005 meeting. Congrex, a meeting planning company from the Netherlands, has participated in two previous World Congress of $G$ astroenterology meetings and will provide invaluable insight. CGI, a meeting planning company from M ontreal, was al so selected by the OM GE and OMED. CGI is well known to the CA G because its current owners were instrumental in planning and organizing the $C$ anadian Digestive Disease W eek meetings from 1996 to 2002, and will provide strong leadership relative to local issues and the scientific program. Indeed, these two companies have al ready demonstrated their willingness to work hand-inhand with the CAG and the World Congress of $\mathrm{G}$ astroenterology $2005 \mathrm{C}$ anadian O rganizing Committee.

In addition to the plethora of details surrounding the holding of a meeting for 15,000 delegates and their families, Canada is responsible for designing and implementing the entire scientific program. Doctors Stephen Collins and Richard H unt have kindly agreed to co-chair the Scientific Program subcommittee and develop what promises to be a stellar evidence-based program.

Since the bid was secured in February 2002, there have been two meetings of the World Congress of $G$ astroenterology 2005 Canadian Organizing Committee and its subcommittees. Each of the subcommittees has developed a series of specific objectives and terms of reference. These subcommittees will now embark upon engaging gastroenterologists from across Canada and around the world to 
TABLE 1

World Congress of Gastroenterology 2005 Canadian Organizing Committee

\begin{tabular}{|c|c|}
\hline \multicolumn{2}{|c|}{ Directors and Committee Chairs and Co-Chairs } \\
\hline President & Richard Fedorak \\
\hline Vice President & Philip Sherman \\
\hline Treasurer* $^{*}$ & Dilip Patel \\
\hline Vice Treasurer & Lawrence Worobetz \\
\hline International Advisory Committee* & Grant Gall \\
\hline Scientific Program Committee (Canadian) ${ }^{*}$ & $\begin{array}{l}\text { Richard Hunt, } \\
\text { Stephen Collins }\end{array}$ \\
\hline Social Program Committee* & Robert Bailey \\
\hline $\begin{array}{l}\text { Young Clinicians Program and } \\
\text { Fellows Program Committee* }\end{array}$ & $\begin{array}{c}\text { Alan Barkun, } \\
\text { Gary Levy }\end{array}$ \\
\hline Publications Committee & Lloyd Sutherland \\
\hline Press and Congress News Committee & $\begin{array}{l}\text { Michel Boivin, } \\
\text { Hugh Chaun }\end{array}$ \\
\hline Public Awareness Committee & $\begin{array}{l}\text { Eldon Shaffer, } \\
\text { Mary Perdue }\end{array}$ \\
\hline CAG Liaison Committee & $\begin{array}{l}\text { Philip Sherman, } \\
\text { Desmond Leddin }\end{array}$ \\
\hline Associated Society Liaison Committee & $\begin{array}{l}\text { Alan Thomson, } \\
\text { Sander van Zanten }\end{array}$ \\
\hline Information Technology Committee & Malcolm Champion \\
\hline Canadian Industry Liaison Committee & Richard Hunt \\
\hline
\end{tabular}

* Required by Organisation Mondiale de Gastro-Entérologie

assist them in meeting these objectives. We encourage you to join any one of these subcommittees and to participate in building the best World Congress of Gastroenterology meeting ever.
Exciting developments that have occurred thus far in the construction of the World C ongress of Gastroenterology 2005 meeting are outlined below:

- The A merican G astroenterological A ssociation (A GA) has agreed to hold its mid-year postgraduate course on the Saturday and Sunday immediately before the start of the W orld C ongress of $\mathrm{G}$ astroenterology 2005 M eeting.

- The International C ourse on Therapeutic Endoscopy has agreed to hold its 2005 meeting during the W orld Congress and to incorporate it directly into the W orld C ongress of $\mathrm{G}$ astroenterology $M$ eeting. This will add an exciting new dimension of world-class live endoscopy to the W orld C ongress of $\mathrm{G}$ astroenterology $2005 \mathrm{M}$ eeting.

- Like the A GA, the Interamerican Society of Gastrointestinal Endoscopy and the Interamerican A ssociation of $\mathrm{G}$ astroenterology (the endoscopy and gastroenterolgy parent organizations of the A mercias, respectively) have agreed to incorporate their postgraduate courses into the mainstream of the $\mathrm{W}$ orld C ongress of $\mathrm{G}$ astroenterology $2005 \mathrm{M}$ eeting. O nce again, this will serve to truly make this a meeting of the A mericas.

- The Young C linicians Program Committee is well on its way to ensuring a stellar program for young clinicians and fellows.

- Hotel accommodation has been secured in Montreal at incredibly competitive rates.

- $\mathrm{N}$ egotiations are underway to ensure that $\mathrm{C}$ anadian gastroenterologists can attend the W orld C ongress 2005 meeting with an extremely attractive registration fee. Stay tuned for more information in this regard.

There are many more developments currently underway, and, as the meeting development unfolds, this column will continue to inform the CA G members of the progress. 


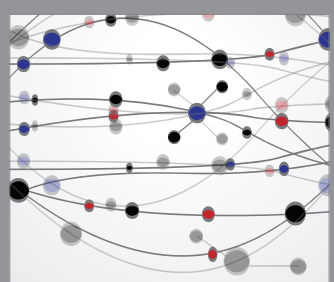

The Scientific World Journal
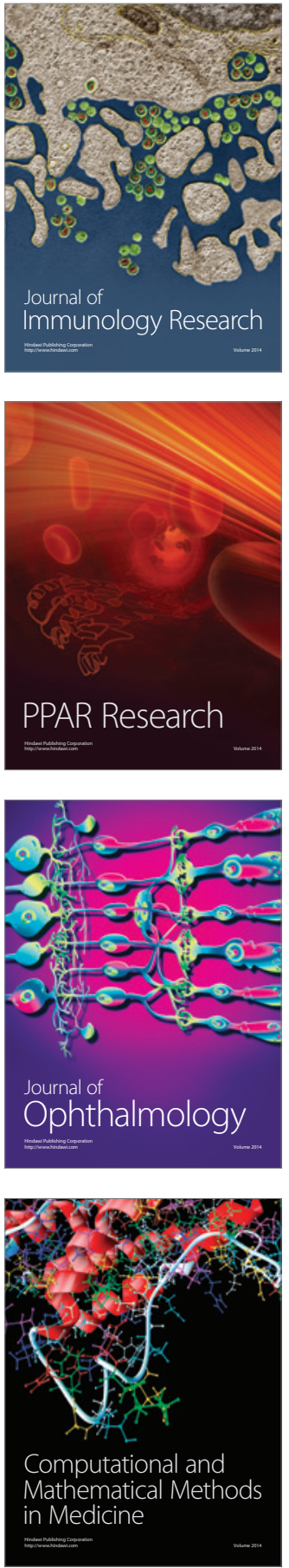

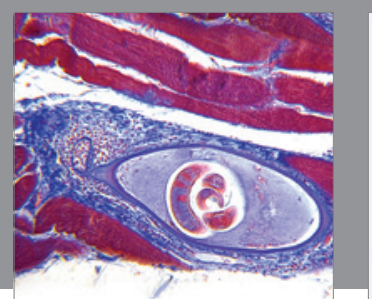

Gastroenterology Research and Practice

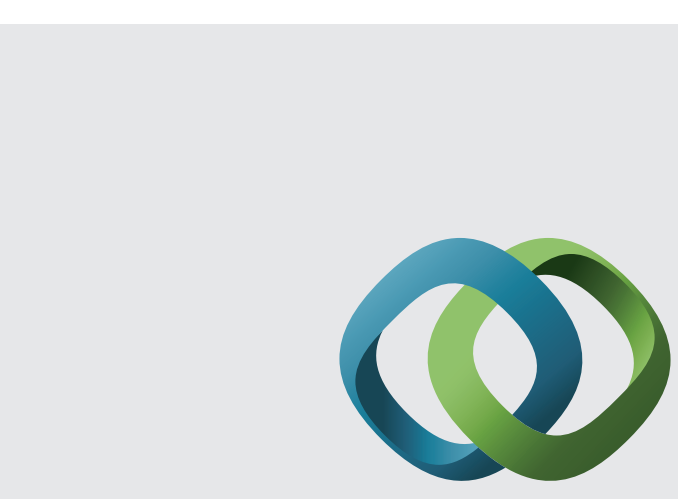

\section{Hindawi}

Submit your manuscripts at

http://www.hindawi.com
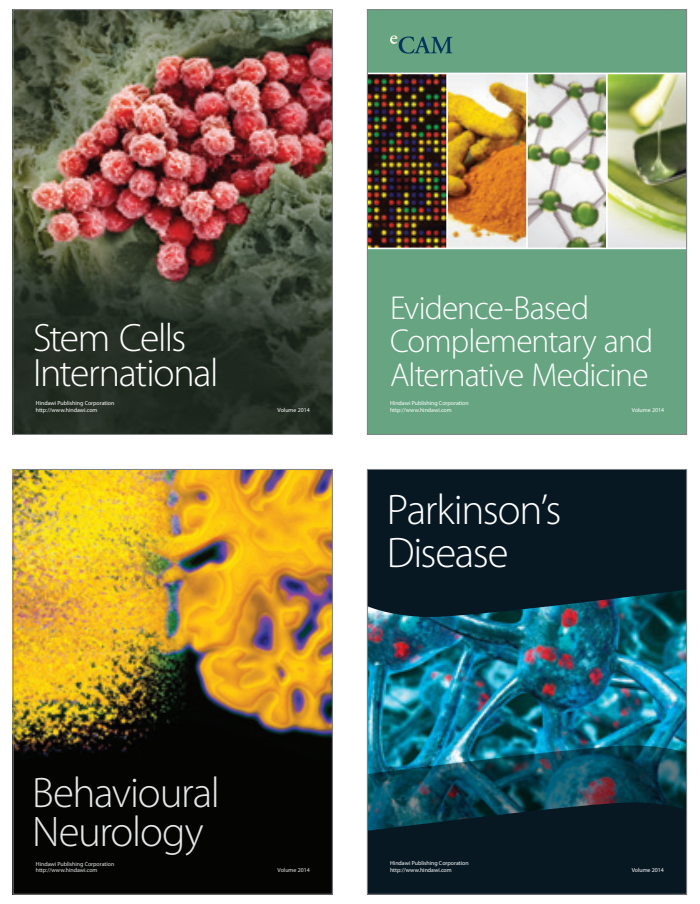
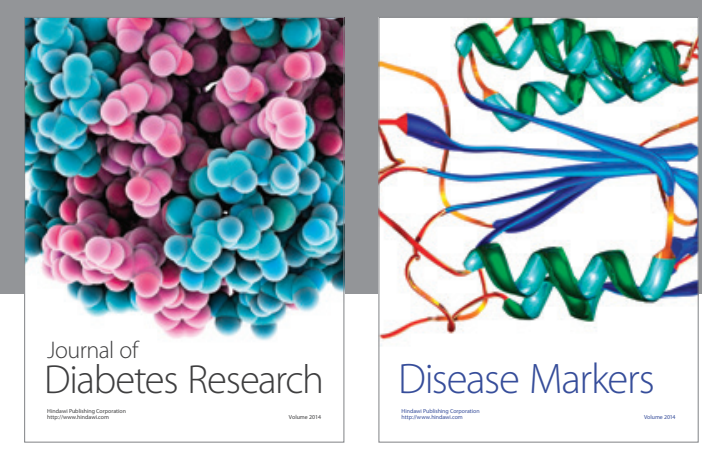

Disease Markers
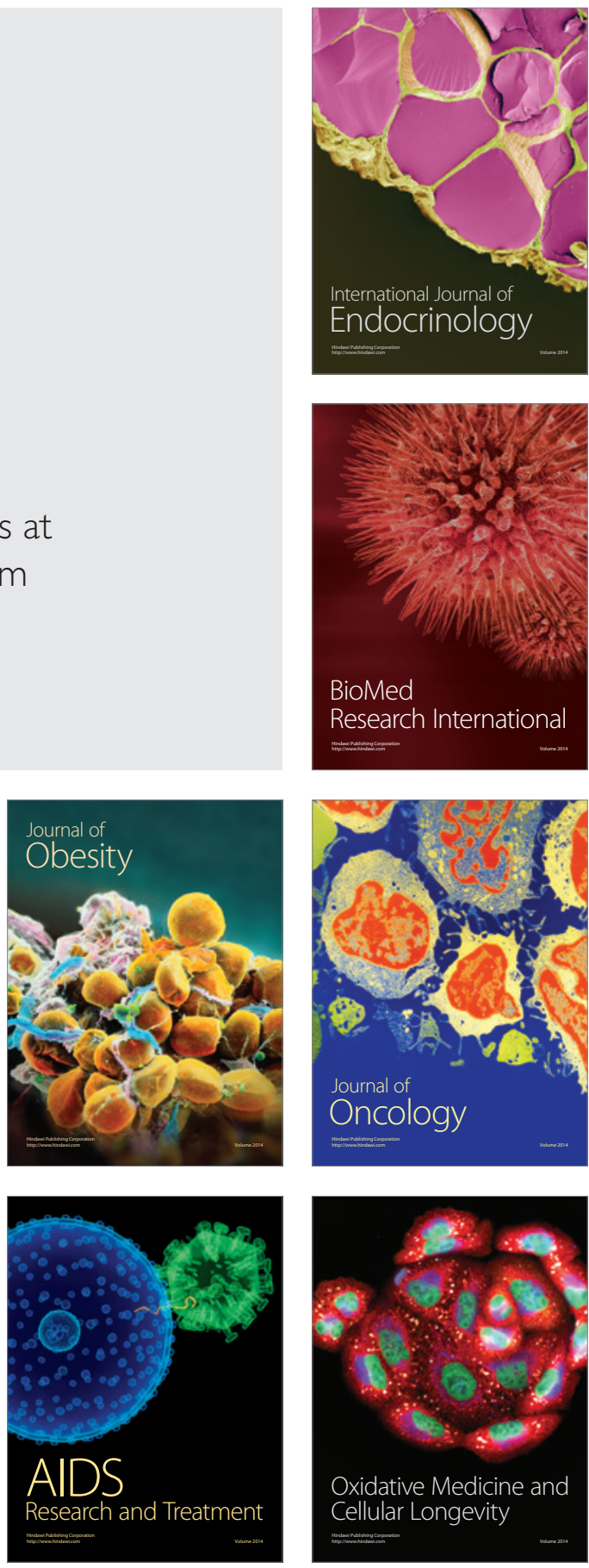